\title{
PENGARUH KEDISIPLINAN, PELATIHAN DAN MOTIVASI KERJA TERHADAP KINERJA KARYAWAN BALAI BESAR WILAYAH SUNGAI BENGAWAN SOLO
}

\author{
Toto Wahono, Ida Aryati, Sri Hartono \\ Program Studi Manajemen, Fakultas Ekonomi UNIBA Surakarta \\ totowahono78@gmail.com
}

\begin{abstract}
Concrete efforts that can support the improvement of the quality of professional performance of employees are training, motivation, and work discipline. These three factors are considered very decisive, because if they are observed and done well, it will have a positive impact on improving the quality of human resources or employee performance. The purpose of the study is to analyze the influence of discipline, training and work motivation simultaneously on employee performance of Big Hall Region Bengawan Solo River. Research is a descriptive study with a quantitative approach. The population of the study was all employees of the Central Bengawan Solo River Region of 600 employees, using Simple Random Sampling taken 25\%, obtained a sample of 150 employees. The technique of collecting data using a questionnaire. The analysis tool uses multiple linear regression analysis. The results of linear regression analysis indicate that discipline, training and work motivation both partially and simultaneously have a significant positive effect on employee performance ( $p$ value <0,05). It is expected that agencies review the discipline of employees by further increasing supervision, providing concessions and encouraging employees to often hold job training in accordance with their duties, can further motivate employees in order to create good performance.
\end{abstract}

Key word: Discipline, Employee Performance, Training, Work Motivation.

\section{PENDAHULUAN}

Perusahaan yang mampu bersaing dan mampu meningkatkan produktivitasnya ditentukan oleh tersedianya SDM yang memiliki kualitas kinerja yang profesional, mempunyai pengetahuan, kemampuan (skill), motivasi dan disiplin tinggi. Dengan memiliki sumber daya manusia yang professional, berkualitas dan unggul akan lebih mudah bagi perusahaan untuk bersaing para kompetitornya. Kualitas sumber daya manusia yang profesional erat berhubungan dengan kinerja karyawan dalam sebuah perusahaan. Untuk mencapai kinerja karyawan yang berkualitas dan profesional, diperlukan tindakan yang konkrit, konsisten dan berkesinambungan. Upaya-upaya konkrit yang dapat mendukung peningkatan kualitas kinerja karyawan yang profesional adalah pelatihan, motivasi, dan disiplin kerja. Ketiga faktor ini dinilai sangat menentukan, sebab jika diperhatikan serta dilakukan dengan baik, maka berdampak positif bagi peningkatan kualitas SDM atau kinerja karyawan (Rumbewas, 2016).

Beberapa hal tersebut juga menjadi sorotan dalam rangka peningkatan kinerja karyawan di Kantor Balai Besar Wilayah Sungai Bengawan Solo. Kantor Balai Besar Wilayah Sungai Bengawan Solo sebagai salah satu organisasi pemerintah yang berhubungan langsung dengan pelayanan pengairan pada masyarakat, berkewajiban untuk terus meningkatkan kualitas pelayanannya kepada masyarakat. Semakin besarnya tuntutan masyarakat terhadap kualitas pelayanan, maka mendorong pihak manajemen Balai Besar Wilayah Sungai Bengawan Solo secara terus menerus untuk melakukan berbagai upaya dalam meningkatkan pelayanan terhadap masyarakat, maka Balai Besar Wilayah Sungai Bengawan Solo harus selalu berupaya meningkatkan kinerja karyawannya dalam rangka memberikan pelayanan yang lebih baik lagi untuk masyarakat 
luas. Oleh karena diperlukan karyawan yang benar-benar terlatih, memiliki disiplin kerja tinggi serta motivasi kerja yang tinggi dalam bekerja.

Kedisiplinan perlu dimiliki oleh setiap orang agar kehidupan organisasi bisa aman, tertib dan lancar. Pelatihan akan memberikan kesempatan bagi karyawan mengembangkan keahlian dan kemampuan baru dalam bekerja agar apa yang diketahui dan dikuasai saat ini maupun di masa yang akan datang dapat membantu karyawan untuk mengerti apa yang seharusnya dikerjakan dan mengapa harus dikerjakan, memberikan kesempatan untuk menambah pengetahuan, keahlian sedangkan melalui motivasi akan memberikan kesempatan kepada karyawan untuk menyalurkan ego individu dan memperkuat komitmen karyawan pada perusahaan (Kusumaningrum, 2015).

Berdasarkan uraian tersebut, maka dalam penelitian ini bertujuan untuk menganalisis pengaruh kedisiplinan, pelatihan dan motivasi kerja baik secara simultan maupun secara parsial terhadap kinerja karyawan Balai Besar Wilayah Sungai Bengawan Solo.

\section{METODE PENELITIAN}

Penelitian merupakan penelitian deskriptif dengan pendekatan kuantitatif. Sumber data penelitian berupadata primer yang diperoleh langsung dari kuesioner yang diisi langsung oleh responden. Metode pengumpulan data menggunakan kuesioner yang telah diuji kevalidan dan kereliabelannya. Populasi dalam penelitian ini adalah seluruh karyawan lai Besar Wilayah Sungai Bengawan Solo sebanyak 600 orang diambil dengan teknik simple random sampling sebesar $25 \%$ maka diperoleh sampel sebanyak 150 orang. Teknik analisis data menggunakan analisis regresi linier berganda.

\section{HASIL PENELITIAN DAN PEMBAHASAN}

\subsection{Hasil Penelitian}

Karakteristik Responden

Tabel 1.Distribusi Karakteristik Responden ( $n=150)$

\begin{tabular}{|c|c|c|}
\hline Karaketristik & Jumlah & Persentase (\%) \\
\hline \multicolumn{3}{|c|}{ Jenis Kelamin } \\
\hline Perempuan & 60 & 40 \\
\hline Laki-laki & 90 & 60 \\
\hline \multicolumn{3}{|c|}{ Umur } \\
\hline 20-30 tahun & 62 & 41,3 \\
\hline 31-40 tahun & 44 & 29,3 \\
\hline 41-50 tahun & 32 & 21,3 \\
\hline 51-60 tahun & 12 & 8,1 \\
\hline \multicolumn{3}{|c|}{ Lama Bekerja } \\
\hline <5 tahun & 12 & 8,1 \\
\hline 5-10 tahun & 53 & 35,3 \\
\hline 11-15 tahun & 51 & 34,0 \\
\hline >15 tahun & 34 & 22,7 \\
\hline \multicolumn{3}{|c|}{ Pendidikan } \\
\hline SMA & 8 & 5,3 \\
\hline Diploma & 32 & 21,3 \\
\hline
\end{tabular}




\begin{tabular}{|l|l|l|}
\hline S1 & 92 & 61,3 \\
\hline S2 & 18 & 12,0 \\
\hline
\end{tabular}

Sumber: Data diolah, 2019

Berdasarkan tabel 1 diatas tampak bahwa dari 150 responden mayoritas responden berjenis kelamin laki-laki $(60 \%)$, berumur $20-30$ tahun $(41,3 \%)$, telah bekerja selama 5-10 tahun $(35,3 \%)$ dan berpendidikan S1 (61,3\%).

\section{Hasil Asumsi Klasik}

\section{Uji Normalitas}

Tabel 2. Hasil Uji Normalitas

\begin{tabular}{|l|l|l|}
\hline Variabel & Probabilitas & Simpulan \\
\hline Unstandardized Residual & 0,339 & Normal \\
\hline
\end{tabular}

Sumber: Data diolah, 2019

Berdasarkan hasil pengujian normalitas terhadap nilai residual diperoleh nilai 0,339. Angka probabilitas ini lebih besar daripada 0,05 ini menjelaskan bahwa data residu hasil estimasi menunjukkan penyebaran data yang normal. Dengan demikian data dalam penlitian ini sudah sesuai dengan persamaan regresi.

\section{Uji Multikolinieritas}

Tabel 3. Hasil Uji Multikolinieritas

\begin{tabular}{|l|c|c|c|}
\hline \multirow{2}{*}{ Variabel } & \multicolumn{2}{|c|}{ Colinearity Statistics } & Simpulan \\
\cline { 2 - 4 } & Tolerance & VIF & \\
\hline Kedisiplinan $\left(\mathrm{X}_{1}\right)$ & 0,761 & 1,314 & Bebas Multikolinieritas \\
\hline Pelatihan $\left(\mathrm{X}_{2}\right)$ & 0,831 & 1,203 & Bebas Multikolinieritas \\
\hline Motivasi Kerja $\left(\mathrm{X}_{3}\right)$ & 0,650 & 1,538 & Bebas Multikolinieritas \\
\hline
\end{tabular}

Sumber: Data diolah, 2019

Dari tabel 3 diketahui bahwa hasil VIF masing-masing variabel berada di bawah nilai 10 dan mempunyai nilai tolerance di atas 0,10 . Hal ini menunjukkan bahwa semua variabel yang digunakan bebas dari masalah multikolinieritas atau tidak terjadi korelasi antara variabel bebas.

\section{Uji Heteroskedasitas}

Tabel 4. Hasil Uji Heteroskedastisitas

\begin{tabular}{|l|c|c|c|}
\hline \multicolumn{1}{|c|}{ Variabel } & thitung & Sig & Simpulan \\
\hline Kedisiplinan $\left(\mathrm{X}_{1}\right)$ & 0,016 & 0,988 & Bebas Heteroskedastisitas \\
\hline Pelatihan $\left(\mathrm{X}_{2}\right)$ & 1,738 & 0,084 & Bebas Heteroskedastisitas \\
\hline Motivasi Kerja $\left(\mathrm{X}_{3}\right)$ & $-0,768$ & 0,444 & Bebas Heteroskedastisitas \\
\hline
\end{tabular}

Sumber: Data diolah, 2019

Dari tabel 4 diketahui bahwa probabilitas variabel kedisiplinan, pelatihan dan motivasi kerja > 
dari 0,05. Hal ini menunjukkan bahwa variabel-variabel tersebut bebas dari masalah heteroskedastisitas.

\section{Uji Hipotesis}

Pengujian hipotesis terdiri dari uji t, F dan koefisien determinasi $\left(\mathrm{R}^{2}\right)$

Tabel 5. Hasil Analisis Regresi Linier Berganda

\begin{tabular}{|l|c|c|}
\hline Variabel Independen & B & Standard Error \\
\hline Konstanta & 12,980 & 1,666 \\
\hline Kedisiplinan $\left(\mathrm{X}_{1}\right)$ & 0,464 & 0,079 \\
\hline Pelatihan $\left(\mathrm{X}_{2}\right)$ & 0,109 & 0,035 \\
\hline Motivasi Kerja $\left(\mathrm{X}_{3}\right)$ & 0,393 & 0,062 \\
\hline
\end{tabular}

Sumber: Data diolah, 2019

Dari tabel 5 dapat disusun persamaan regresi sebagai berikut:

$$
Y=12,980+0,464 X_{1}+0,109 X_{2}+0,393 X_{3}+e
$$
berikut:

Dari persamaan regresi tersebut, adapun interpretasi yang dapat dijelaskan adalah sebagai

a. $a=12,980$. Ini merupakan konstanta, yang artinya bahwa konstanta senilai 12,980 menyatakan jika tidak ada nilai kedisiplinan, pelatihan dan motivasi kerja maka kinerja karyawan sebesar 12,980 .

b. $b_{1}=0,464$. Artinya jika skor variabel kedisiplinan meningkat satu poin maka kinerja karyawan akan meningkat sebesar 0,464 (dengan asumsi variabel pelatihan dan motivasi kerja dianggap nol).

c. $b_{2}=0,109$. Artinya jika skor variabel pelatihan meningkat satu poin maka kinerja karyawan akan meningkat sebesar 0,109 (dengan asumsi variabel kedisiplinan dan motivasi kerja dianggap nol).

d. $b_{3}=0,393$. Artinya jika skor variabel motivasi kerja meningkat satu poin maka kinerja karyawan akan meningkat sebesar 0,393 (dengan asumsi variabel kedisiplinan dan pelatihan dianggap nol).

\section{Uji Kelayakan Model (Uji F)}

Tabel 6. Hasil Uji F

\begin{tabular}{|l|c|c|c|l|}
\hline Variabel Dependen & Fhitung & Ftabel & pvalue & Simpulan \\
\hline Kinerja Karyawan (Y) & 66,430 & 2,67 & 0,000 & Signifikan \\
\hline
\end{tabular}

Sumber: Data diolah, 2019

Pada tabel 6 dapat dilihat bahwa nilai Fhitung sebesar 66,430 > Ftabel $(2,67)$ dengan probabilitas sebesar 0,000 (pvalue $<0,05$ ). Hal ini berarti kedisiplinan, pelatihan dan motivasi kerja berpengaruh positif signifikan terhadap kinerja karyawan, sehingga hipotesis kesatu (H1) diterima. Hal ini juga menunjukkan bahwa model regresi yang digunakan adalah fit atau sehat (goodness of fit), sehingga model penelitian ini layak untuk digunakan. 
Uji t

Tabel 7. Hasil Uji t

\begin{tabular}{|l|c|c|c|l|}
\hline \multicolumn{1}{|c|}{ Variabel } & thitung & ttabel & $p$ value & \multicolumn{1}{c|}{ Simpulan } \\
\hline Kedisiplinan (X1) & 5,849 & 1,976 & 0,000 & Signifikan \\
\hline Pelatihan (X2) & 3,136 & 1,976 & 0,002 & Signifikan \\
\hline Motivasi Kerja (X3) & 6,341 & 1,976 & 0,000 & Signifikan \\
\hline
\end{tabular}

Sumber: Data diolah, 2019

Berdasarkan tabel 7 dapat diketahui bahwa variabel kedisplinan memiliki nilai t hitung sebesar 5,849 lebih besar dari ttabel sebesar 1,976 dengan nilai signifikansi $0,000<0,05$ yang artinya kedisiplinan berpengaruh positif signifikan terhadap kinerja karyawan, sehingga hipotesis kedua $\left(\mathrm{H}_{2}\right)$ diterima.

Variabel pelatihan memiliki nilai thitung sebesar 3,136 lebih besar dari ttabel sebesar 1,976 dengan nilai signifikansi $0,002<0,05$ yang artinya pelatihan berpengaruh positif signifikan terhadap kinerja karyawan, sehingga hipotesis ketigas $\left(\mathrm{H}_{3}\right)$ diterima.

Variabel motivasi kerja memiliki nilai thitung sebesar 6,341 lebih besar dari t tabel sebesar 1,976 dengan nilai signifikansi $0,000<0,05$ yang artinya motivasi kerja berpengaruh positif signifikan terhadap kinerja karyawan, sehingga hipotesis keempat $\left(\mathrm{H}_{4}\right)$ diterima.

\subsection{Pembahasan}

\section{Pengaruh Kedisiplinan, Pelatihan dan Motivasi Kerja Secara Simultan terhadap Kinerja Karyawan}

Kedisiplinan, pelatihan dan motivasi kerja berpengaruh positif signifikan terhadap kinerja karyawan, sehingga hipotesis kesatu $\left(\mathrm{H}_{1}\right)$ diterima. Dengan demikian dapat diartikan bahwa semakin tinggi kedisiplinan karyawan didukung dengan semakin sering karyawan mengikuti pelatihan dan motivasi kerja yang tinggi dari karyawan maka akan semakin meningkatkan kinerja karyawan Balai Besar Wilayah Sungai Bengawan Solo, begitu pula sebaliknya. Kedepannya diharapkan kinerja karyawan Balai Besar Wilayah Sungai Bengawan Solo selalu meningkat, sehingga dapat tercipta suasana yang nyaman dan tentram bagi karyawan.

Hasil penelitian ini memperkuat hasil penelitian yang dilakukan oleh Sahangggamu dan Mandey (2014); Rumbewas (2016); Munir dkk (2017), Permadi et all (2018) dimana masingmasing hasil penelitian mereka memberikan bukti empiris bahwa secara simultan kedisiplinan, pelatihan dan motivasi kerja berpengaruh signifikan terhadap kinerja karyawan.

\section{Pengaruh Kedisiplinan terhadap Kinerja Karyawan}

Kedisiplinan berpengaruh positif signifikan terhadap kinerja karyawan sehingga hipotesis kedua $\left(\mathrm{H}_{2}\right)$ diterima. Hasil penelitian ini dapat diartikan bahwa semakin tinggi kedisiplinan karyawan maka semakin meningkatkan kinerja karyawan begitu pula sebaliknya. Dengan demikian, untuk meningkatkan kinerja para karyawan, maka pimpinan Balai Besar Wilayah Sungai Bengawan Solo dapat selalu mengawasi karyawan, memberikan sanksi tegas jika melanggar, mampu memberikan contoh dalam penggunaan waktu secara efektif terkait penyelesaian pekerjaan serta mampu memberikan contoh terkait lebih bertanggung jawab dalam menyelesaikan pekerjaan. Variabel ini dapat mempengaruhi tingkah dan perbuatan yang tidak muncul dengan sendirinya, tetapi perlu dibentuk terhadap kineja karyawan. Hal ini dikarenakan dengan disiplin kerja yang tinggi, kinerja karyawan akan semakin berpengaruh pula.

Hasil penelitian ini didukung oleh hasil penelitian sebelumnya yaitu penelitian Widodo dkk (2018); Untari (2018); Burhanuddin dkk (2017); Ranu dan Sutopo (2016) menunjukan bahwa 
kedisiplinan berpengaruh terhadap kinerja karyawan.

\section{Pengaruh Pelatihan Terhadap Kinerja Karyawan}

Pelatihan berpengaruh positif signifikan terhadap kinerja karyawan, sehinggahipotesis ketiga $\left(\mathrm{H}_{3}\right)$ diterima. Hal ini dapat diartikan bahwa semakin sering karyawan mengikuti pelatihan maka akan semakin mendukung meningkatnya kinerja karyawan, begitu pula sebaliknya. Oleh karena itu pihak pimpinan dan petinggi instansi harus semakin memberikan banyak kesempatan yang seluasluasnya bagi karyawan untuk mengikuti berbagai macam pelatihan sesuai dengan tupoksinya masing-masing di kantor. Semakin banyak pelatihan, akan meningkat pengembangan kinerja karyawan.

Hasil penelitian ini memperkuat hasil penelitian sebelumnya yang dilakukan oleh Sefriady dan Iskandar (2018); Widodo dkk (2018); Hayati dan Haryani (2016) memberikan bukti empiris bahwa pelatihan berpengaruh signifikan terhadap kinerja karyawan.

\section{Pengaruh Motivasi Kerja Terhadap Kinerja Karyawan}

Motivasi kerja berpengaruh positif signifikan terhadap kinerja karyawan, sehingga hipotesisi keempat $\left(\mathrm{H}_{4}\right)$ diterima. Dari analisis uji t diketahui bahwa variabel motivasi kerja mempunyai pengaruh yang paling dominan terhadap kinerja karyawan dibanding kedua variabel independen lainnya. Motivasi yang mendasari seseorang melaksanakan pekerjaan merupakan faktor yang amat penting dan paling mempengaruhi terhadap kinerja karyawan. Oleh karena itu peran pimpinan instansi harus lebih aktif agar lebih mendorong pegawai sebagai bentuk motivasi dalam pencapaian tujuan instansi. Hal yang dapat dilakukan oleh instansi agar dapat meningkatkan kinerja pegawainya antara lain dengan pemberian penghargaan bagi pergawai yang berprestasi dengan memberikan beasiswa untuk melanjutkan pendidikan yang lebih tinggi atau dapat berupa kompensasi seperti hadiah yang dapat memicu kreatifitas kerja mereka.

Hasil penelitian ini memperkuat hasil penelitian sebelumnya yang dilakukan oleh Munir dkk (2017); Ranu dan Sutopo (2016); Rachmawati (2016) memberikan bukti empiris bahwa motivasi kerja berpengaruh signifikan terhadap kinerja karyawan.

\section{KESIMPULAN DAN SARAN}

\section{Kesimpulan}

Hasil penelitian menunjukkan bahwa Kedisiplinan, pelatihan dan motivasi kerja berpengaruh positif signifikan terhadap kinerja karyawan baik secara parsial maupun secara simultan. Sehingga dapat diartikan bahwa dengan meningkatkan kedisiplinan, pelatihan dan motivasi kerja maka akan dapat meningkatkan kinerja karyawan.

\section{Saran}

Berdasarkan kesimpulan diatas maka dapat diberikan beberapa saran sebagai berikut:

1. Bagi Instansi Balai Besar Wilayah Sungai Bengawan Solo

a. Diharapkan meninjau kembali penerapan dan aturan tentang kedisiplinan karyawan dengan lebih meningkatkan pengawasan aturan disiplin kerja baik secara tegas pemberian sanksi/hukuman terhadap pelanggaran disiplin.

b. Diharapkan pihak manajemen instansi dan pimpinan memberikan kelonggaran dan mendorong agar para karyawan sering mengadakan pelatihan kerja sesuai tupoksinya sehingga mampu meningkatkan kinerjanya.

c. Diharapkan lebih meningkatkan motivasi kerja karyawan dengan memperhatikan hal-hal yang dapat memotivasi karyawan dalam rangka menciptakan kinerja yang baik sehingga peran karyawan itu sendiri dapat lebih maksimal dalam mencapai tujuan. 
2. Bagi peneliti selanjutnya

a. Diharapkan peneliti menggunakan variabel yang lebih bervariasi dengan menambah variabel lainnya yang mampu mempengauhi kinerja karyawan dengan penambahakan metode intervening ataupun moderating implementasi.

b. Penelitian selanjutnya sebaiknya tidak hanya menggunakan metode survei dengan cara menyebarkan kuesioner saja, tetapi juga ditambah dengan melakukan wawancara secara langsung kepada para karyawan (depth interview), sehingga diperoleh data secara lengkap dna komprehensif.

c. Diharapkan memperluas obyek penelitian tidak hanya instansi namun bisa bervariatif ke perusahaan swasta ataupun instansi lainnya sebagai pembanding hasil penelitian yang dapat memperkuat ataupun memperlemah hasil penelitian ini.

\section{DAFTAR PUSTAKA}

Burhanuddin, Nurul Qomari, dan Abdul Fattah. 2017. Pengaruh Pelatihan, Disiplin Dan Lingkungan Kerja Terhadap Kinerja Karyawan Pada PT. Federal International Finance Group (FIF) Cabang Surabaya. Jurnal Manajemen Branchmark Vol 3 Issue 3, 2017: 544-555.

Hayati, Nur dan Sri Haryani. 2016. Pengaruh Pelatihan, Kepemimpinan, Dan Motivasi Terhadap Kinerja Karyawan Pada PD BPR Bank Jogja Yogyakarta. Telaah Bisnis Volume 17, Nomor 1, Juli 2016: 19-34.

Kusumaningrum, Fitra Rachman. 2015. Pengaruh Gaya Kepemimpinan, Disiplin Kerja, Dan Pelatihan Terhadap Kinerja Karyawan Di Rumah Sakit Umum Daerah Gambiran Kota Kediri. Artikel Skripsi. Program Studi Manajemen Fakultas Ekonomi Universitas Nusantara PGRI Kediri.

Munir, Andi Abdul; Bakri Hasanuddin; dan Saharuddin Kaseng. 2017. Pengaruh Pelatihan, Disiplin Dan Motivasi Terhadap Kinerja Pegawai Pada Badan Pengelolaan Keuangan Dan Asset Daerah Provinsi Sulawesi Tengah. e Jurnal Katalogis, Volume 5 Nomor 3, Maret 2017 hlm 153-164.

Permadi, Bayu, I. B. Ag. Dharmanegara, dan Ni Wayan Sitiari. 2018. The Effects Of Leadership And Motivation Againsts Work Discipline And Performance Of Civil Servant Employees At Balai Wilayah Sungai Bali Penida. JAGADHITA:Jurnal Ekonomi \& Bisnis, Vol. 5, No 1. Maret 2018, Hal 46-57.

Rachmawati, Watie. 2016. Pengaruh Pelatihan Dan Motivasi Kerja Terhadap Kinerja Karyawan PT Bank BJB Kantor Cabang Suci Bandung. Jurnal Manajemen dan Pemasaran Jasa Vol . 9 No. 1 2016: 1-16.

Ranu, Saifu dan Sutopo. 2016. Pengaruh Motivasi Kerja Dan Disiplin Kerja Terhadap Kinerja Pegawai Pada Dinas Tata Kota Dan Perumahan Kota Semarang. Dharma Ekonomi No.44 / Th.XXIII/ Oktober 2016: 65-77.

Rumbewas, Cornelia. 2016. Analisis Pengaruh Pelatihan, Motivasi Dan Disiplin Kerja Terhadap Kinerja Karyawan (Studi Pada Karyawan Bank BRI Kantor Wilayah Jayapura). Skripsi. Fakultas Ekonomika Dan Bisnis Universitas Diponegoro Semarang.

Sahanggamu, Patricia M. dan Silvya L. Mandey. 2014. Pengaruh Pelatihan Kerja, Motivasi, Dan Disiplin Kerja Terhadap Kinerja Karyawan Pada PT. Bank Perkreditan Rakyat Dana Raya. Jurnal EMBA Vol.2 No.4 Desember 2014, Hal. 514-523. 
Sefriady, Dea Fanny dan Donant Alananto Iskandar. 2018. Pengaruh Pelatihan dan Disiplin Kerja Terhadap Kinerja Pegawai di Biro Organisasi dan Kepegawaian Sekretariat Jenderal Kementerian Perdagangan. Jurnal Elektronik REKAMAN (Riset Ekonomi Bidang Manajemen dan Akuntansi) Sekolah Tinggi Ilmu Ekonomi Galileo. Vol. 2 No. 1 May 2018: 57-68.

Untari, Dewi. 2018. Pengaruh Displin Kerja Terhadap Kinerja Pegawai Pada PT. KIE Indonesia. Cano Ekonomos, Volume 7 Nomor 1 Januari 2018: 1-15.

Widodo, Trenggono; Nanang Alamsyah; dan Chandyka Bagus Utomo. 2018. Analisis Pengaruh Gaya Kepemimpinan, Disiplin Kerja Dan Pelatihan Kerja Terhadap Kinerja Karyawan Di PT Telkom Indonesia Cabang Batam. Jurnal Industri Kreatif (JIK) Februari 2018 | Vol. 2 | No. 1: 97-104. 